\title{
Towards Understanding the Late Neolithic of the Egyptian Western Desert: Gebel Ramlah, Site E-16-02
}

\author{
Jacek Kabaciński ${ }^{a}$, Agnieszka Czekaj-Zastawny ${ }^{b}$, \\ Hebatallah A. A. Ibrahim ${ }^{c}$ and Jakub Mugaj ${ }^{d}$
}

\begin{abstract}
The research around the palaeo-lake of Gebel Ramlah has revealed the presence of numerous remains of Late Neolithic occupation. One such site - E-16-02 - was excavated in 2018 and delivered unique evidence pointing to the specific style of life of human groups here in the later Neolithic. In the light of the available evidence, it seems that the occupation was seasonal and the site was visited several times. Its main feature was an oven, carefully designed and regularly cleaned as it served for cooking food during subsequent visits to the place. The remaining features were occasionally constructed during each stay. The distribution of flint artefacts, chaotic, unpatterned, without visible places of flint processing and lacking clear links with features and remains of pottery vessels also indicate multiple visits to the site. This pattern is obviously different to that recognized during the Holocene climatic optimum when the extent of the settlements was substantially larger accompanied by a diversity of features indicating a stable, long-lasting occupation (Al Jerar Unit).
\end{abstract}

KEY-WORDS: Prehistoric Egypt, Western Desert, Late Neolithic, pottery, flint industry, settlement pattern

\section{INTRODUCTION}

The beginning of the Holocene brought to NE Africa, as elsewhere in the Northern Hemisphere (Alley et al., 1993; Lowe et al., 2008), a radical improvement of climatic conditions (Kuper and Kröpelin 2006). From the beginning of the Holocene,

a Institute of Archaeology and Ethnology, Polish Academy of Sciences, Rubież Street 46, 6I-6I2 Poznan, Poland; e-mail: jacek.kabacinski@interia.pl; ORCID: 0000-0002-2118-2005

$b$ Institute of Archaeology and Ethnology, Polish Academy of Sciences, Sławkowska Street 17, 3I-oI6 Cracow, Poland; e-mail: aczekajzastawny@gmail.com; ORCID: 0000-0001-6171-9930

c Oriental Institute, University of Oxford, United Kingdom; e-mail: hebatallah.ibrahim@orinst.ox.ac.uk; ORCID: 0000-0002-0682-4233

d Institute of Archaeology and Ethnology, Polish Academy of Sciences, Rubież Street 46, 6I-6I2 Poznan, Poland; e-mail: j_mugaj@o2.pl; ORCID: 0000-0002-2822-2962 
I80 |Jacek Kabaciński, Agnieszka Czekaj-Zastawny, Hebatallah A. A. Ibrahim and Jakub Mugaj

c. $9550 \mathrm{BC}$, the area of today's Sahara, being in the Upper Pleistocene a vast deserted territory, witnessed seasonal rains allowing the development of a savanna environment. That obviously attracted different fauna species and, in consequence, also humans.

A typical landscape feature of the Egyptian Southwestern Desert at that time, an area located in the eastern part of the Sahara, was the presence of temporary lakes - playas - that were fed by rain waters in a yearly cycle. Around those lakes during the early and middle Holocene numerous human groups settled, leaving differentiated traces of occupation dated from $c .9300$ (Schild and Wendorf 2013) to the mid third millennium $\mathrm{BC}$ at the latest when the Sahara was a severe desert again (Applegate and

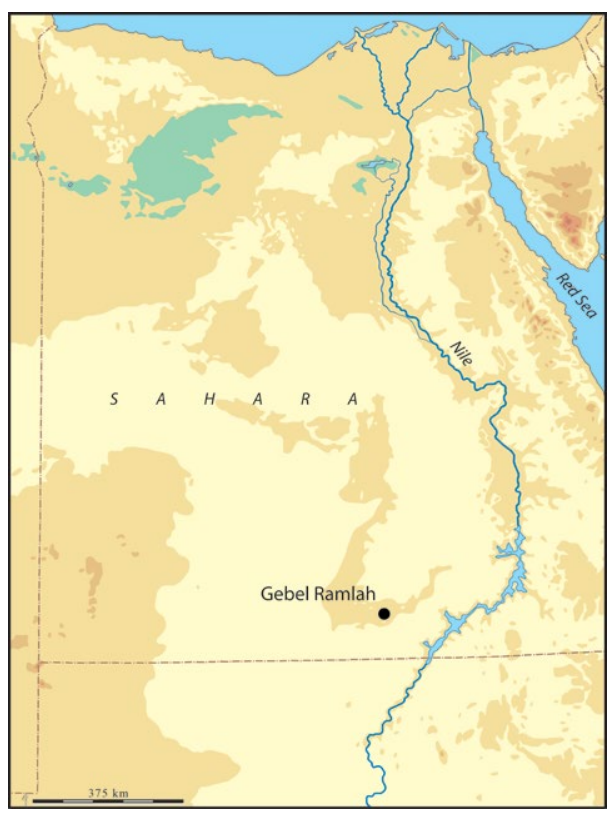

Fig. I. Location of Gebel Ramlah. Computer graphics: I. Jordan. Zedeño 200I).

One such an area is located $c .150 \mathrm{~km}$ west of the Nile Valley near the pronounced mountain called Gebel Ramlah (Fig. I). The lonely mountain, with its top elevated at $c .250 \mathrm{~m}$ a.s.l., rises $c .100 \mathrm{~m}$ above the surrounding desert. Beneath its southern slopes a lake extended during the large part of the Holocene that, according to results of our current investigations, filled partially the basin that carried waters already in the Middle Pleistocene (Fig. 2).

Research in Gebel Ramlah begun in 2000 when M. Kobusiewicz and K. Banks discovered the first cemeteries there (Kobusiewicz et al., 2004; 2010) and has continued till today within new projects. In the years 2009-2015, the main research effort concentrated on burial practices while since 2016 a dominating goal was the recognition of settlement patterns in the context of numerous occupation traces recorded around the palaeo-lake (Czekaj-Zastawny and Kabaciński 20I5; Czekaj-Zastawny et al., 20I8a; 20I8b; Kabaciński et al., 2018; 2019).

Based on current knowledge, the earliest traces of human presence in this region are perhaps related to the so-called El Adam Unit but the first evident occupation is linked with the Early Holocene El Ghorab Unit (Schild and Wendorf 2013). The first unquestionable sedentary populations appeared here during the climatic optimum of the Holocene - the Al Jerar Unit around 6500-600o BC, followed by the pastoral Middle, Late and Final Neolithic groups. The end of human occupation is placed at 


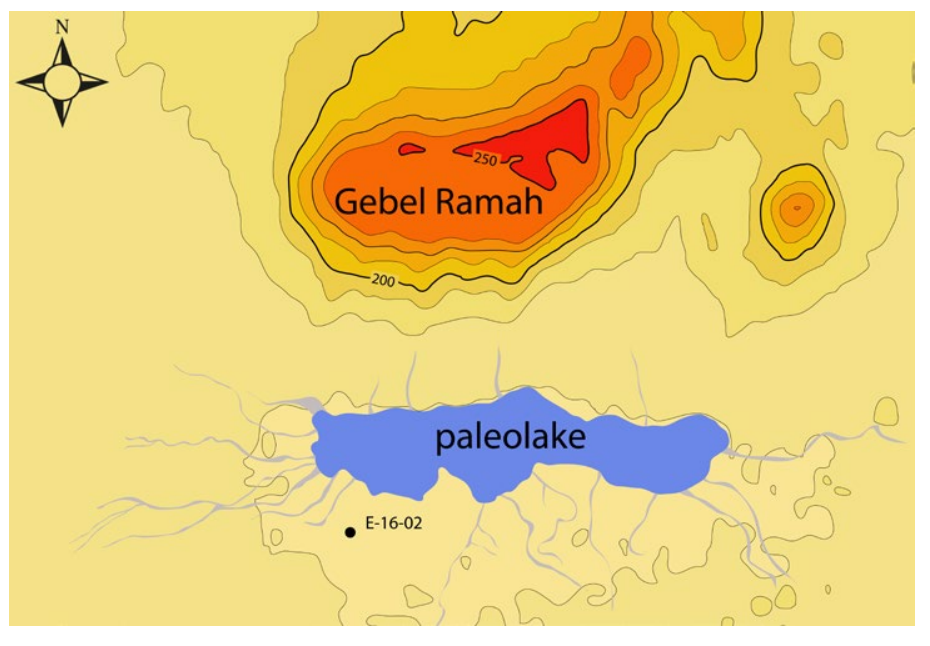

Fig. 2. Gebel Ramlah. Approximate extent of the Holocene lake and site E-16-02. Computer graphics: J. Kabaciński.

c. $4300 \mathrm{BC}$ and is related with the last of the above-mentioned chronostratigraphic units. The diverse traces of hunter-gatherer and pastoral societies preserved along the shores of the palaeo-lake as well as the wadis feeding the lake basin with rain waters, including numerous remains of stable and shortly used settlements, traces of short-lived camps and other activities as well as burials. The characteristic feature of the Final Neolithic were the cemeteries dated to 4500-4300 BC (Kobusiewicz et al., 20I0; Czekaj-Zastawny et al., 20I8a; Kabaciński et al., 2018; 2019).

The present paper discuss the evidence from the later part of the settlement sequence recorded at Gebel Ramlah, namely a small but distinct settlement of the Late Neolithic period. It produced unique evidence pointing to the specific style of life of human groups at that time. The first evidence of the Late Neolithic occupation was indicated by radiocarbon dates made on charcoal from hearths recorded on sites E-01-01 and E-01-02 CAMP (Bobrowski et al., 2006; Schild and Wendorf 20I0). This was supported later by several Late Neolithic burials (Kabaciński et al., 2019). The site discussed here is the first extensively excavated settlement of that period.

\section{SITE E-16-02}

The site was discovered in 2016 during the field prospection of the southeastern shores of the paleolake. It is located on a small hillock on the western edge of a small wadi running north to the lake (Fig. 2 and 3). The site is approximately $50 \mathrm{~m}$ in diameter. On the surface, concentrations of archaeological material were recorded consisting of 
I82 Jacek Kabaciński, Agnieszka Czekaj-Zastawny, Hebatallah A. A. Ibrabim and Jakub Mugaj

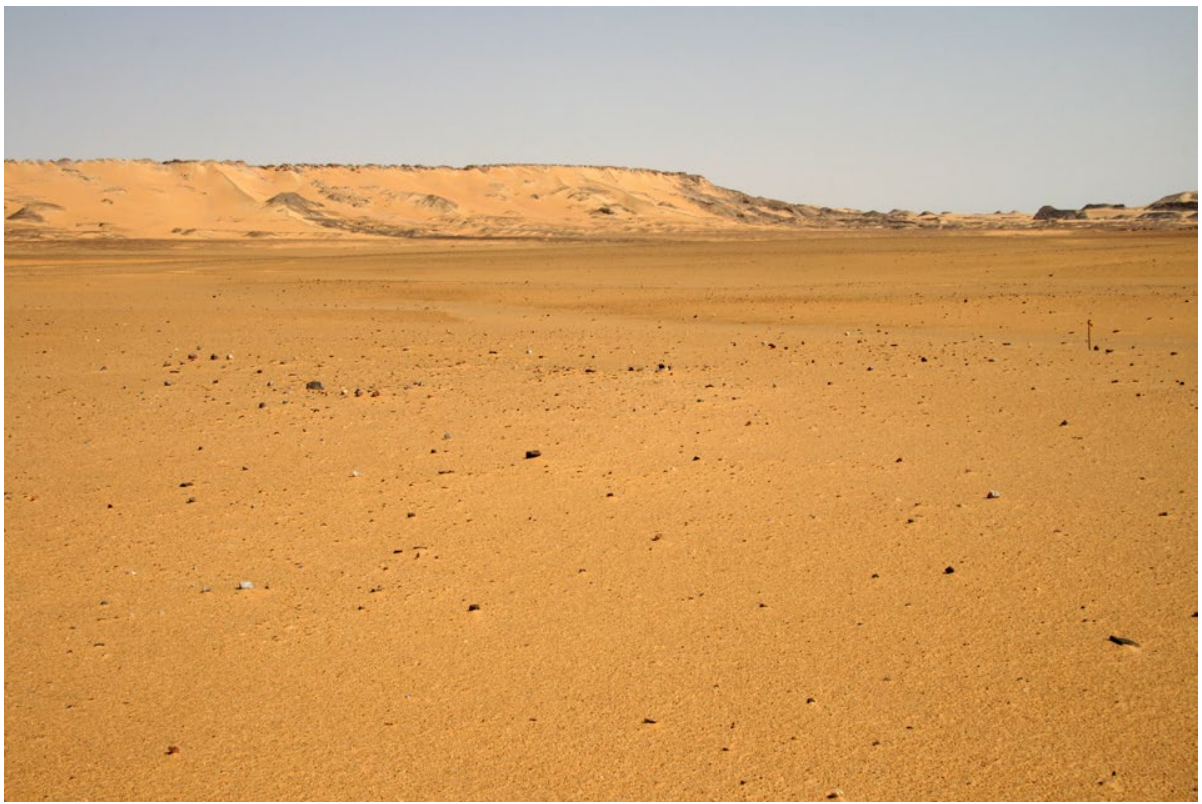

Fig. 3. Gebel Ramlah. View of the E-16-02 site from the south. Photo: A. Czekaj-Zastawny.

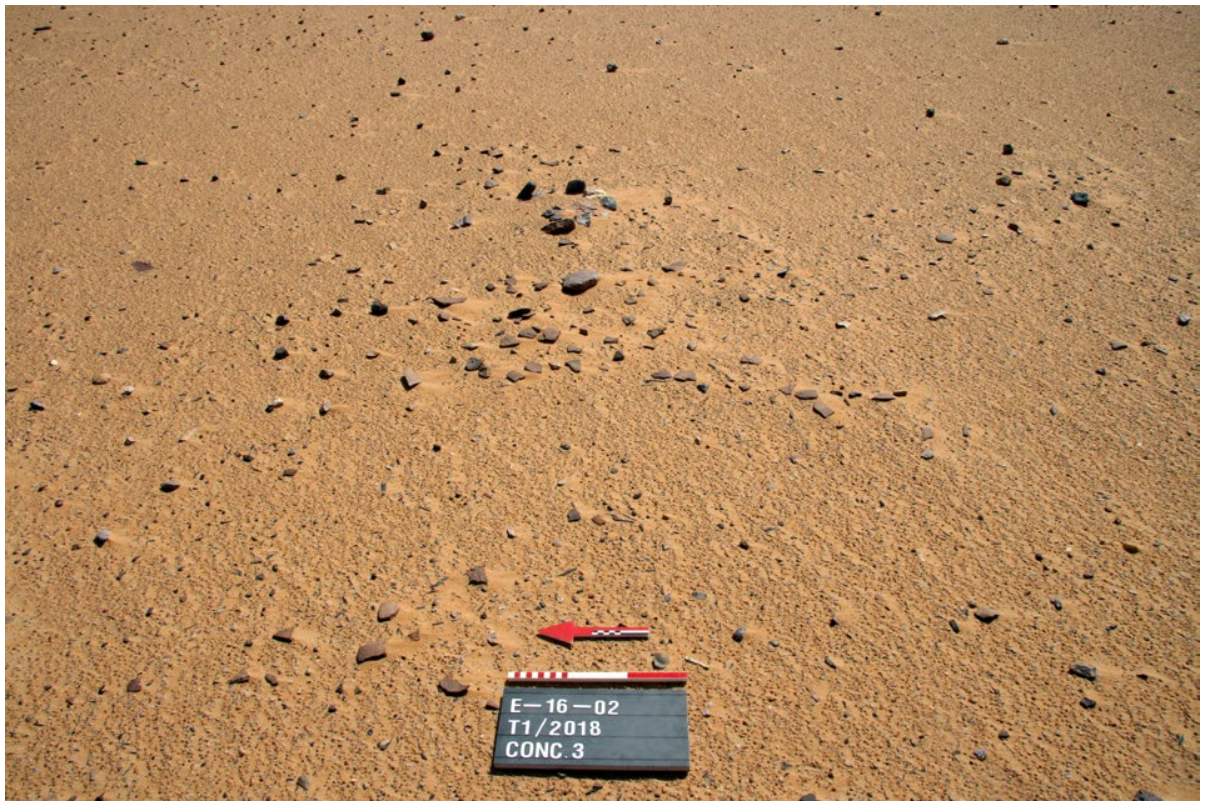

Fig. 4. Gebel Ramlah, site E-16-02. Concentration of archaeological material on the surface. Photo: A. Czekaj-Zastawny. 
traces of stone structures, pottery fragments, animal bones and lithics (Fig. 4). In 20I8, a trench of 250 sq. $\mathrm{m}$ was excavated producing several features including six pits and a few small fireplaces marked by red-burnt silt. In total, 1373 pottery fragments, 2840 chert artefacts, 3452 animal bone fragments (cattle and sheep/goat), I24 fragments of stone tools (small fragments of hand grinders and grinding stones) and 250 fragments of ostrich egg shells were recorded. Only 158 artefacts were found in the pits. Detailed analysis of the find material was done for all the pits and material from an area of Ioo sq. m (sq. no. 5) where the density of artefacts was the highest.

\section{Features}

Three types of features were recorded on the site: oven, charring pit and a short-used hearth.

\section{Oven}

One feature of this kind was recorded (feature no. 1; Fig. 5). On the surface it was visible as an oval concentration of stones measuring $c .90 \times 45 \mathrm{~cm}$, including 7 fragments of one grinding stone and 3 handstones (Fig. 6A). In the profile it appeared as a depression paved with flat stones laying close one to another. It looked like a stone open bowl (Fig. 6B). Between and below these stones numerous charcoal fragments were found as well as red-burnt silt. The feature was filled with consolidated sand lacking charcoal and artefacts. The only artefacts were found in the topmost layer on edges of the feature and seem to be post-consumption remains. These are mainly animal bones (c. Ioo fragments). Therefore it is probable the feature was systematically cleaned out after each use.

\section{Charring pit}

Five such features were found, distributed at a distance of several metres around the oven, except on the western side, each measuring $c$. I0o $\mathrm{cm}$ along longer axis (Fig. 5). The most characteristic element of this category of feature is the presence of a regular rectangular or oval depression made of red-burned silt. The fills of the majority of these features consisted of consolidated sand with rare pieces of charcoal and single stones (Fig. 7). Most probably these features were used for charring wild plants (seeds?).

\section{Short-used hearth}

Five hearths of this type were present within the excavated area, usually circular, very small, up to $40 \mathrm{~cm}$ in diameter and shallow (to $5 \mathrm{~cm}$ ). No stone construction is connected with them. They were preserved in the field in the form of spots of a red-burnt silt without charcoal and artefacts. All but one were situated on the western side of the oven (Fig. 5). 
I84 Jacek Kabaciński, Agnieszka Czekaj-Zastawny, Hebatallah A. A. Ibrahim and Jakub Mugaj

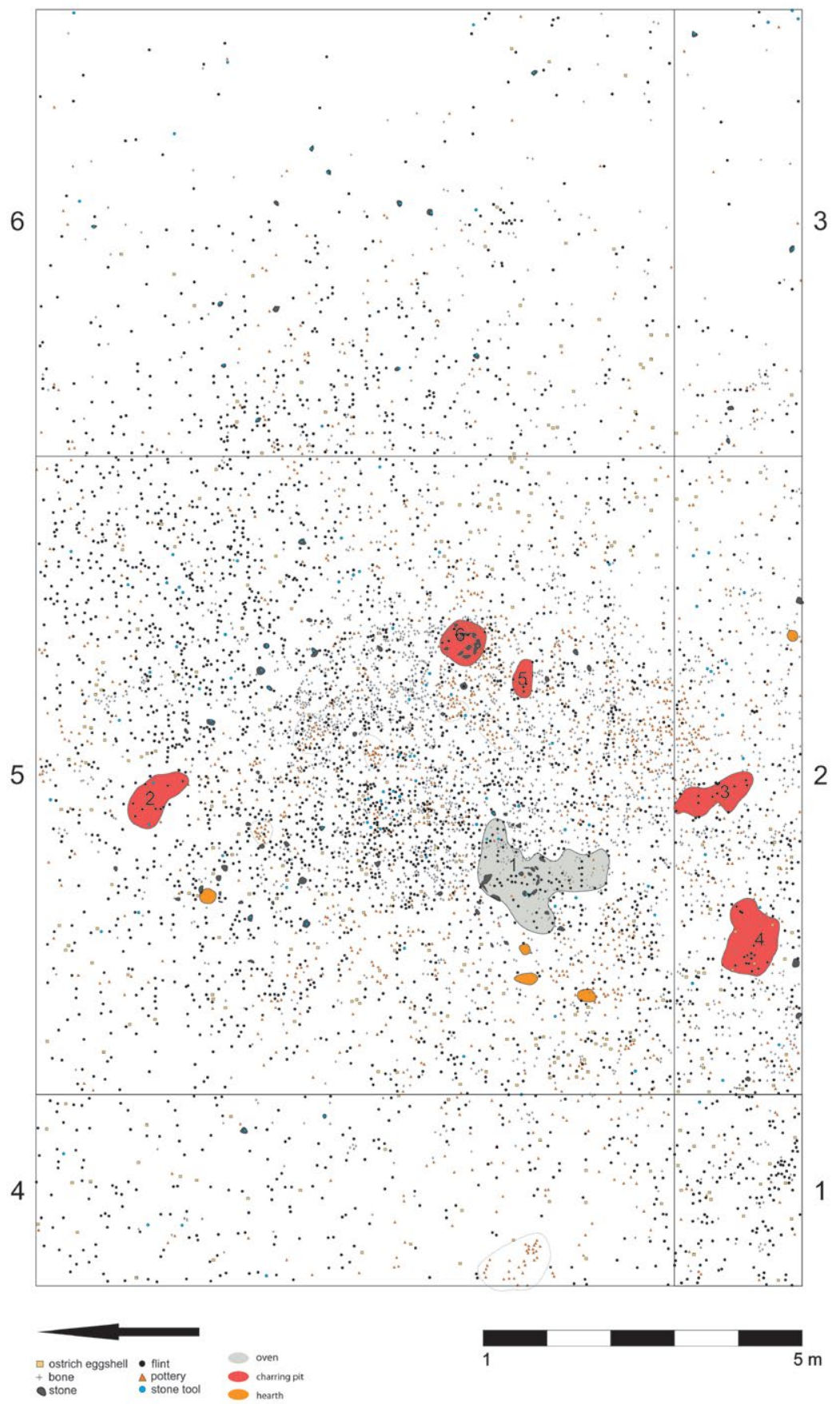

Fig. 5. Gebel Ramlah, site E-16-02. Distribution of features and archaeological artefacts. Drawn: J. Mugaj. 
Towards Understanding the Late Neolithic of the Egyptian Western Desert... $\mid$ I85

\section{Pottery}

Among the 860 pottery sherds analyzed, $\mathrm{I} 3$ rims and 847 morphologically non-characteristic fragments were distinguished. Only 23 pieces come from features: II fragments from feature no. 1 and I2 fragments from feature no. 2. The remaining sherds come from the area between features. Some fragments are well preserved and they allow a comprehensive description of the analysed assemblage. Several fragments from around the hearths are secondarily burnt.

Among the ceramic assemblage all the fragments were identified as smoothed red and brown wares, according to the typology of M. Gatto (Gatto 1998; 1999; 2010). This type of pottery is characteristic of the Late Neolithic in the Western Desert.

Only eight vessel shapes could be identified. Most of them (five examples) were spherical bowls (one from feature no. 1), two were small bowls and one sherd appeared to be a fragment of a wide-open bowl (Fig. 8). All the vessels are undecorated, with rounded rims. One of the fragments has a hole (c.4 mm in diameter), made after firing. This probably indicates an attempt to repair the broken vessel.

The wall surfaces are usually brown in colour and smoothed, usually matte, sometimes burnished. The thickness varied between $4-9 \mathrm{~mm}$, but mostly 4-6 $\mathrm{mm}$. A few fragments with a thickness of $8-9 \mathrm{~mm}$ seem to belong to larger pots.

The fabric of the vessels was very well prepared, e.g., thoroughly mixed, with fine grained admixture. Pottery is mostly tempered with fine sand and sometimes with a very small amount of plant admixture. When it comes to sand, thin-sections of pottery can only explain whether it is a natural inclusion (from the use of sources of clay with natural sand) or an intentional admixture. According to M. Gatto (1998; 1999; 2010), the intentional organic admixture was used only from the Late Neolithic on (in earlier periods vegetable inclusions came from the use of clay from the lake shore with natural plant fractions).

\section{Lithics}

A total number of 2840 lithics were analysed. Almost all of them were registered on the surface and do not form any concentrations but were scattered rather evenly not revealing particular spatial structures. Only twelve non-diagnostic lithic artefacts were found within the features.

The raw material used for lithic production was mostly chert that dominates over the less frequent quartz, agate, petrified wood and sandstone.

The lithic technology was a simple unidirectional flaking technology based on the exploitation of single and multi-platform cores. The preparation and rejuvenation of the cores was very limited. Within the group of 20 cores found, the multi-platform type dominated over single and opposed platform ones. Only two cores can be identified as used for blade production. The clear flake character of the technology is also 
I86 Jacek Kabaciński, Agnieszka Czekaj-Zastawny, Hebatallah A. A. Ibrahim and Jakub Mugaj

indicated by the structure of debitage. A total number of 354 flakes were registered (mostly detached from single platform cores) while only io specimens are blades.

The assemblage from square 5 produced I84 retouched tools (Fig. 9). Almost half of the tools are retouched flakes. The second most numerous group are denticulate pieces. Two chisel-like bifacial tools and two knife-like blades also occurred. Another category of tools are specimens made mostly on blades such as diverse non-standardized perforators, borers and truncations. The assemblage contains single examples of microliths: two
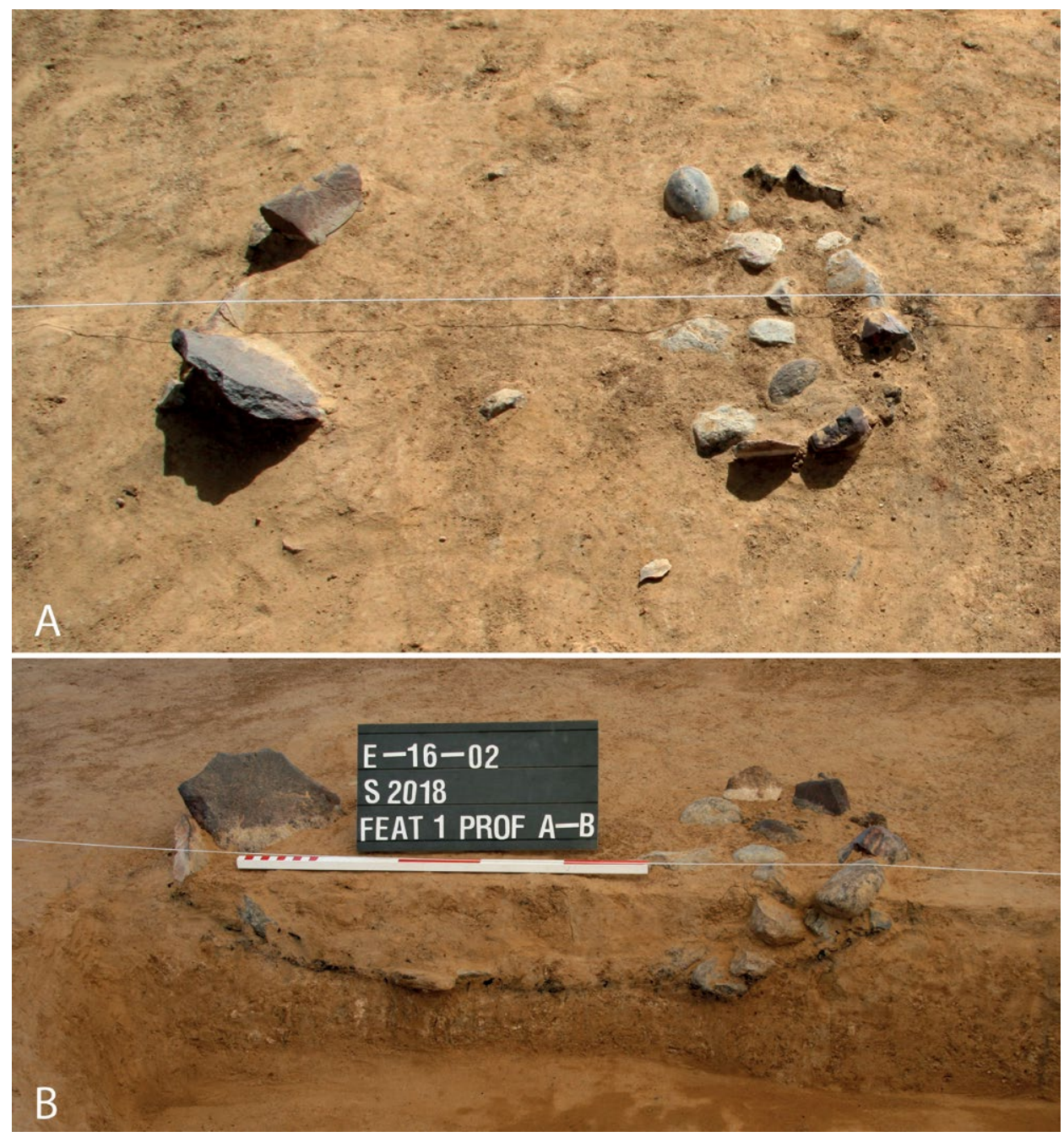

Fig. 6. Gebel Ramlah, site E-16-02. Feature 1. Photo: A. Czekaj-Zastawny. 
arched backed pieces, a backed piece, a triangle and two lunates. A single microburin was recorded as well.

The analyzed lithics are typical of the Late Neolithic. This is indicated by the simplified technology based on unipolar reduction and often change of core orientation in the last stage of processing. The lithic technology was concentrated on the production of short, wide flakes that were processed into non-characteristic denticulate tools or retouched flakes. Single bifacial tools and lunates appear as well.

\section{SITE CHRONOLOGY}

The studied pottery assemblage indicates human presence on the site in the late stage of the Neolithic. The "smoothed red" and "brown" ceramic wares, without ornamentation, are characteristic for this period (Gatto 1998; 1999; 20I0). That is in accordance with the nature of the lithic assemblage dominated by production of flakes with characteristic denticulated and bifacial tools and segments.

According to the basic chrono-stratigraphic units of the later Neolithic occupation of the Western Desert correlated with climatic fluctuations (Schild and Wendorf 20I3), the Late Neolithic Humid Interphase is dated to c. 5500-4650 BC (6500-5800 uncalibrated BP), and the Final Neolithic Humid Interphase to $c .4600-3600 \mathrm{BC}$ (5750-4800 uncalibrated BP).

The radiocarbon measurement made of cattle bone gave the result $5650 \pm 40 \mathrm{bp}$ (POZ90397) which (after calibration $-4484 \pm 43 \mathrm{BC})^{1}$ places the settlement at the beginning of the Final Neolithic. However, as the analysis was made of a carbonate, the date should be considered a minimal one, therefore the settlement was most probably in use at the very end of the Late Neolithic. On the other hand, the latest radiocarbon AMS determinations made on materials from a secure context suggest a human presence within a dry period between the Late and Final Neolithic (Kabaciński et al., 2019), which raises basic questions on the correlations between human settlement and the climatic phases distinguished for the Nabta-Kesiba region (Schild and Wendorf 2013).

\section{DISCUSSION}

In the course of the excavations, it appeared that concentrations of finds visible on the surface do not correspond to with distribution pattern recorded below the surface. This is the result of various activities undertaken on the site and directly related to the discovered features. Concentrations of pottery are in most cases numerous fragments

1 Calibrated with CalPal2007_HULU; http://www.calpal-online.de 
I88 Jacek Kabacinski, Agnieszka Czekaj-Zastawny, Hebatallah A. A. Ibrabim and Jakub Mugaj
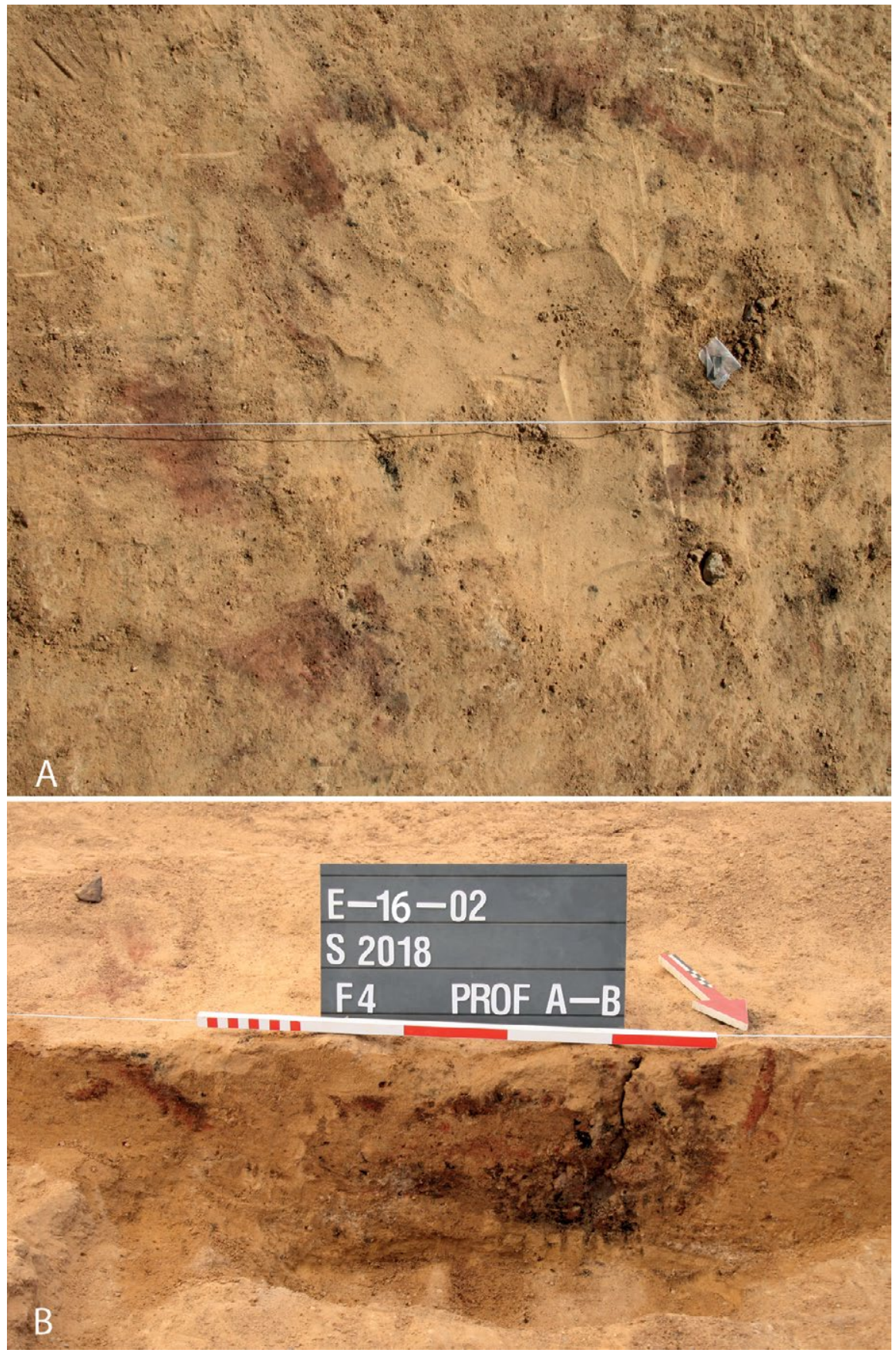

Fig. 7. Gebel Ramlah, site E-16-02. Feature 4. Photo: A. Czekaj-Zastawny. 
of one and the same vessel and, together with the animal bones can be localized and linked with everyday life at the settlement. However, we cannot say the same in respect to the chert artefacts. The horizontal distribution of lithics (Fig. 5) does not show any clear pattern (also in functional sense) and as such reflects deposition and dispersal during multiple visits to the site. This is also confirmed by the presence of several features of the same type used for the same purpose in close proximity to each other.

In the light of above evidence, it seems that the occupation was a seasonal and the present state of the site was a result of it being visited several times. Its main feature was an oven, carefully designed and regularly cleaned as it served for cooking food during subsequent visits to the place. The remaining features were periodically created during each stay. The distribution of the flint artefacts, chaotic, unpatterned, without visible places of flint processing and lacking clear links with features and the remains of the pottery vessels indicates multiple visits to the site.

According to current research, the Late Neolithic settlements were limited in size and located along the wadis reaching the lake from the south. That is a different pattern from that known from the climatic optimum of the Holocene. At that time - the Al Jerar Unit - settlements were much larger, with clearly visible and developed system of spatial distribution of various features and constructions. In the Late Neolithic settlements, in turn, the diversity of features is limited to the basic categories necessary to short-time occupation.

\section{CONCLUSIONS}

The research at site E-16-02 revealed the presence of short-lived seasonal settlement where the economic activities undertaken were limited in scale. The place was visited several times, during the wet season at the end of the Late Neolithic. It was placed, as were the majority of other such occupation sites, on the banks of a small wadi. We still don't know exactly what kind of food was processed in the features that were found. What is confirmed without doubt is the presence of cattle. We may only assume that wild grasses/sorghum might have been heat-treated in the charring pits as in earlier times (Wasylikowa et al., 200I). That will hopefully be clarified in the nearest future.

The seasonality of the settlements is also confirmed by the presence of single burials scattered within the larger area and located at a substantial distance from the settlement zones. It seems this was a specific pattern of all the Late Neolithic settlement of the Gebel Ramah area, based on seasonal, short-lived camps rather than large and stabile occupation sites. This had most probably caused by the progressing desertification of the region due to major climatic changes (Schild and Wendorf 2013). 
I90 Jacek Kabaciński, Agnieszka Czekaj-Zastawny, Hebatallah A. A. Ibrahim and Jakub Mugaj
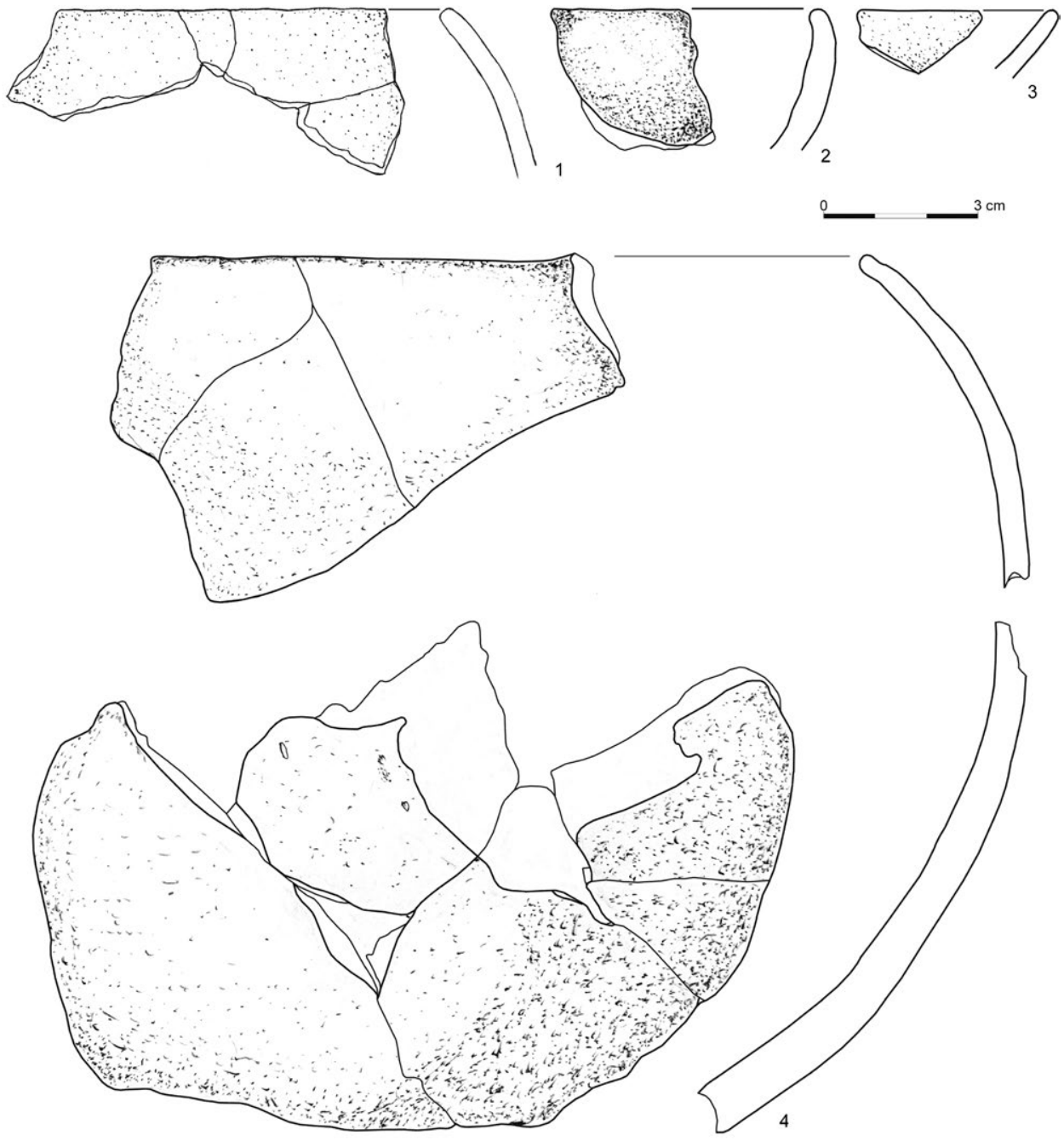

Fig. 8. Gebel Ramlah, site E-16-02. Selection of pottery. I, 4-spherical bowls; 2, 3-open bowls. Drawn: J. Jędrysik. 

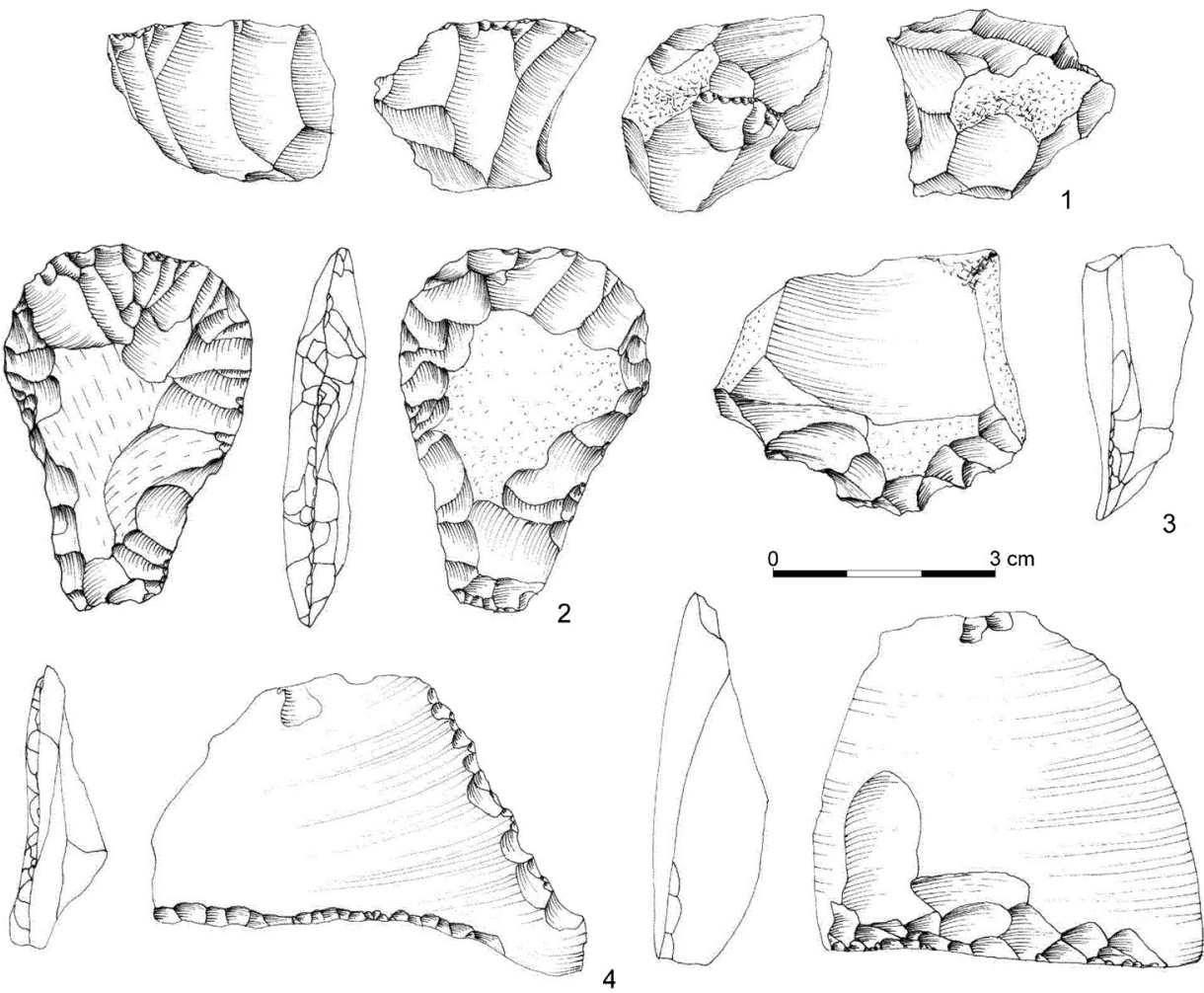

3
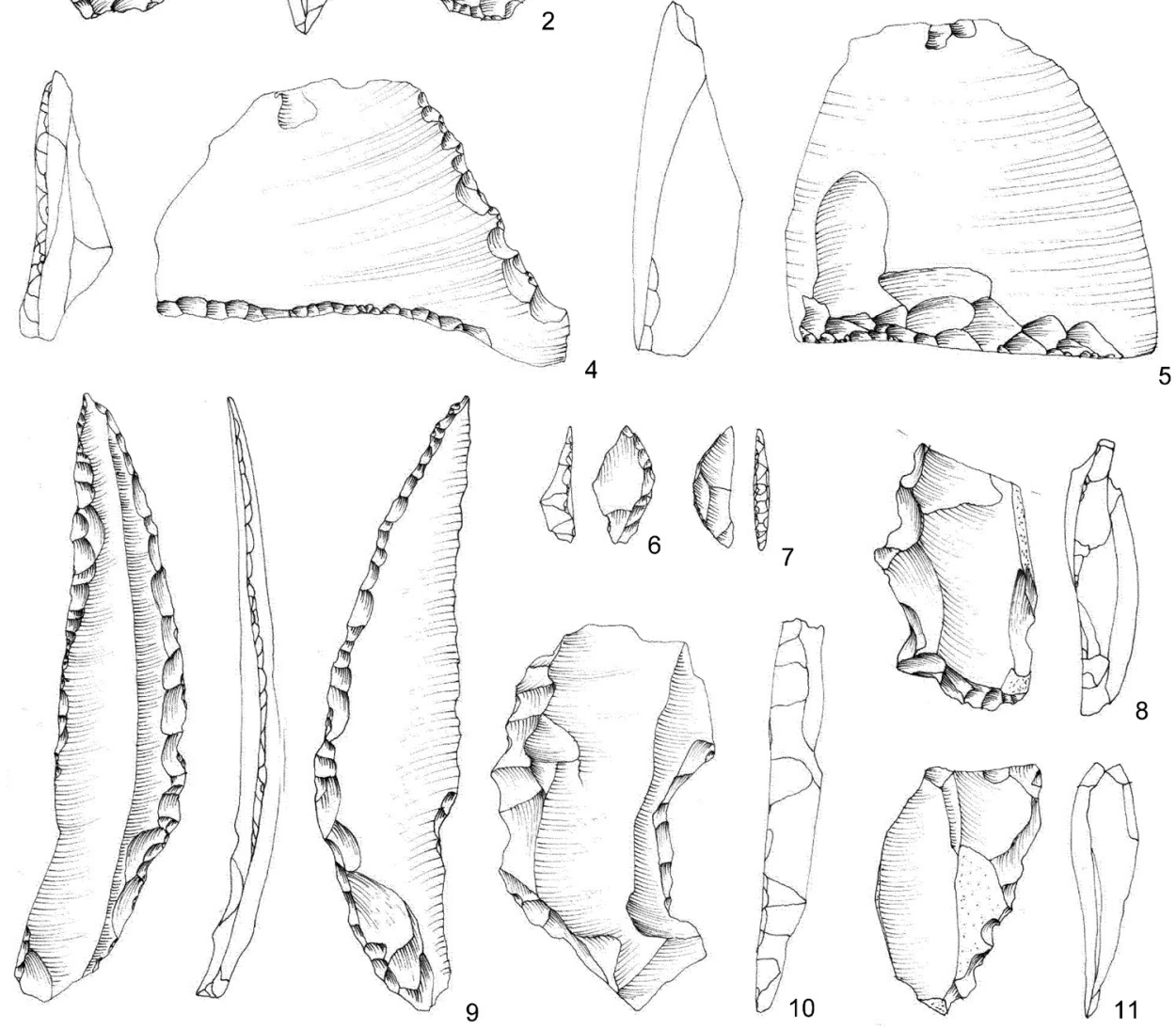

Fig. 9. Gebel Ramlah, site E-16-02. Selection of lithic artefacts. I - core with changed orientation; 2-chisel-like bifacial tool; 3, 8, IO, II - denticulated flakes; 4, 5-retouched flakes; 6, 7 - lunates; 9 - knife-like tool. Drawn: J. Mugaj. 
192 Jacek Kabaciński, Agnieszka Czekaj-Zastawny, Hebatallah A. A. Ibrahim and Jakub Mugaj

\section{ACKNOWLEDGEMENTS}

The research was sponsored by the Polish National Science Centre (grant No. 2012/05/B/HS3/03928, and grant No. 2017/25/B/HS3/02385) and by the Combined Prehistoric Expedition Foundation. The authors would like to thank both institutions for that support.

\section{REFERENCES}

Alley, R. B., Meese, D. A., Shyman, C. A., Gow, A. J., Taylor, K. C., Grootes, P. M., White, J. W. C., Ram, M., Paddington, E. D., Mayewski, P. A. and Zieliński, G. A. 1993. Abrupt increase in Greenland snow accumulation at the end of Younger Dryas event. Nature 362: 527-529.

Applegate, A. and Zedeño, N. 200I. Site E-92-8: A late prehistoric C-group component at Nabta Playa. In F. Wendorf, R. Schild and Associates (eds), Holocene Settlement of the Egyptian Sahara, vol. I. The Archaeology of Nabta Playa, 529-533. New York, Boston Dordrecht, London, Moscow.

Bobrowski, P., Schild, R. and Calderonii, G. 2006. Late Neolithic Settlements (E-01-2 “CAMP”) from the Gebel Ramlah Playa Basin, South-Western Desert of Egypt (Preliminary Report). In K. Kroeper, M. Chłodnicki and M. Kobusiewicz (eds), Archaeology of Early Northeastern Africa. In Memory of Lech Krzyżaniak, 213-222. Poznań. Studies in African Archaeology 9.

Czekaj-Zastawny, A. and Kabaciński, J. 20I5. New Final Neolithic cemetery E-09-4, Gebel Ramlah Playa, Western Desert of Egypt. In J. Kabaciński, M. Chłodnicki and M. Kobusiewicz (eds), Huntergatherers and early food producing societies in the Northeastern Africa, 375-384. Poznań. Studies in African Archaeology I4.

Czekaj-Zastawny, A., Goslar, T., Irish, J. D. and Kabaciński, J. 20r8a. Gebel Ramlah - a Unique Newborns' Cemetery of the Neolithic Sahara. African Archaeological Review. https://doi.org/10.1007/ s10437-018-9307-1.

Czekaj-Zastawny, A., Irish, J., Kabaciński, J. and Mugaj, J. 20r8b. The Neolithic settlements by a paleolake of Gebel Ramlah, Western Desert of Egypt. In J. Kabaciński, M. Chłodnicki, M. Kobusiewicz and M. Winiarska-Kabacińska (eds), Desert and the Nile Prehistory of the Nile Basin and the Sahara. Papers in honour of Fred Wendorf, 515-538. Poznań. Studies in African Archaeology 15.

Gatto, M. C. 1998. The Late Neolithic pottery decorations from Nabta Playa. CPE Interim Report for the Egyptian Supreme Council of Antiquities. Unpublished manuscript, Archive of the Combined Prehistoric Expedition.

Gatto, M. C. 1999. The Late Neolithic pottery decorations from Nabta Playa. CPE Interim Report for the Egyptian Supreme Council of Antiquities. Unpublished manuscript, Archive of the Combined Prehistoric Expedition.

Gatto, M. C. 2oio. Pottery from Gebel Ramla. In M. Kobusiewicz, J. Kabaciński, R. Schild, J. Irish, M. Gatto and F. Wendorf, Gebel Ramlah. Final Neolithic Cemeteries from the Western Desert of Egypt, I23-158. Poznań.

Kabaciński, J., Czekaj-Zastawny, A. and Irish, J. D. 20I8. The Neolithic Infant Cemetery at Gebel Ramlah in Egypt's Western Desert. In S. Han, T. K. Betsinger and A. B. Scott (eds), The anthropology of the fetus. Biology, Culture, and Society, I32-I45. New York-Oxford. 
Kabaciński, J., Czekaj-Zastawny, A. and Irish, J. D. 2019. The Neolithic of Gebel Ramlah, vol. I. Cemetery for Newborns. Poznań.

Kobusiewicz, M., Kabaciński, J., Schild, R., Irish, J. D. and Wendorf, F. 2004. Discovery of the first Neolithic cemetery in Egypt's Western Desert. Antiquity 78(30I): 566-579.

Kobusiewicz, M., Kabaciński, J., Schild, R., Irish, J. D., Gatto, M. and Wendorf, F. 2010. Gebel Ramlah. Final Neolithic cemeteries from the Western Desert of Egypt. Poznan.

Kuper, R., and Kröpelin, S. 2006. Climate-controlled Holocene occupation in the Sahara: motor of Africa's evolution. Science 313: 803-807.

Lowe, J. J., Rasmussen, S. O., Björck, S., Hoek, W. Z., Steffensen, J. P., Walker, M. J. C., Yu, Z. C. and the INTIMATE group. 2008. Synchronisation of palaeoenvironmental events in the North Atlantic region during the Last Termination: a revised protocol recommended by the INTIMATE group. Quaternary Science Reviews 27: 6-17.

Schild, R. and Wendorf, F. 2010. Geomorphology, lithostratigraphic environment and paleoecology of Neolithic camps and cemeteries at Gebel Ramlah Playa. In M. Kobusiewicz, J. Kabaciński, R. Schild, J. D. Irish, M. Gatto and F. Wendorf, Gebel Ramlah. Final Neolithic Cemeteries from the Western Desert of Egypt, I59-186. Poznań.

Schild, R. and Wendorf, F. 20I3. Early and middle Holocene paleoclimates in south western desert of Egypt - the World before unification. Studia Quaternaria 30(2): 125-133.

Wasylikowa, K., Barakat, H. N. and Lityńska-Zając, M. 20or. Seeds and Fruits. In F. Wendorf, R. Schild and Associates (eds), Holocene Settlement of the Egyptian Sahara, vol. I. The Archaeology of Nabta Playa, 605-606. New York, Boston, Dordrecht, London, Moscow. 
